\title{
Tratamiento de los efluentes de la industria del cuero en la ciudad de Arequipa
}

\section{Treatment of Effluents of the Industry of the Leather in the Arequipa City}

\author{
Rosa María Sotomayor Zúñiga*
}

http://dx.doi.org/10.21503/CienciayDesarrollo.2006.v7.04

\section{RESUMEN}

La ciudad de Arequipa solo cuenta con una planta de tratamiento de aguas residuales que da servicio al $8 \%$ de las aguas servidas que produce la ciudad. El $92 \%$ de las aguas residuales de origen doméstico, industrial y hospitalario son arrojadas crudas al río Chili. Dichas aguas no solo contienen sustancias tóxicas de origen industrial, sino que además transportan altas concentraciones de coliformes y una carga bacteriana y patológica significativa, ya que ningún hospital ni centro de salud de la ciudad de Arequipa cuenta con sistema de pretratamiento de sus aguas antes de ser vertidas a la red de colectores locales. Esta situación se agrava si se considera que dichas aguas son utilizadas para el riego de los cultivos de pan llevar y follaje para la alimentación del ganado vacuno de zonas como La Joya y otras áreas agrícolas aledañas a la ciudad. Dichas áreas agrícolas abastecen de productos alimenticios a los propios habitantes de la ciudad de Arequipa, por lo que existe el riesgo potencial de una epidemia generalizada.

En general, la zona industrial y las áreas urbanas no están separadas, y por lo tanto las aguas residuales industriales y las aguas servidas urbanas se mezclan en los ríos, dificultándose de este modo la determinación del aporte de contaminación que le corresponde a la industria. Sin duda, las industrias en la ciudad contribuyen con una porción de carga en relación a la carga contaminante total. Sin embargo, aún se desconoce la real magnitud del aporte de cada industria, debido a la falta de información técnica y a la actitud poco cooperativa de estas.

La investigación está enfocada en el desarrollo de una propuesta para optimizar los procesos productivos, utilizando tecnologías alternativas bioquímicas para el tratamiento de sus aguas residuales.

La investigación puede justificarse desde los siguientes puntos de vista:

- Justificación tecnológica: se determinarán los parámetros tecnológicos adecuados para los tratamientos previos de los efluentes industriales antes de que estos sean vertidos al desagüe y posteriormente al río Chili.

- Justificación social: el río Chili dejará de ser un río muerto, ya que sus aguas llevarán una carga de residuos de cromo mínima, la misma que será monitoreada para no superar el límite permisible dado por las normas internacionales.

Se puede disminuir el grado de contaminación de cromo de los efluentes de la industria del curtido en Arequipa, con la recuperación de algunos aditivos y mediante un tratamiento con plantas acuáticas.

Las variables involucradas son:

Variable dependiente: concentración de cromo III y cromo total en agua tratada $(\mathrm{mg} / \mathrm{l})$.

Variables independientes: concentración de cromo III y cromo total en agua de alimentación $(\mathrm{mg} / \mathrm{l})$, tiempo de residencia en el humedal (min), seguimiento del desarrollo natural de las plantas (vitalidad, color de hojas, crecimiento del tallo y hojas, concentración de cromo III y cromo total en la raíz y tallo de las plantas).

Palabras clave: cromo III, coliformes, efluentes, aguas residuales.

\footnotetext{
* Universidad Alas Peruanas, Arequipa.
} 


\section{ABSTRACT}

The city of Arequipa only counts on a plant of waste water treatment that gives service to $8 \%$ of the served waters that produces the city. Meaning that $92 \%$ of waste waters of domestic, industrial and hospitable origin are thrown crude to the Chili River. These waters not only contain toxic substances of industrial origin, but also that entail discharges concentrations of coliforms and significant a bacterial and pathological load, since no hospital nor center of health of the city of Arequipa tell on system of pre treatment of its waters before being spilled to the network of local collectors. This situation worsens if it is considered that these waters are used for the irrigation of the bread cultures to take and foliage for the feeding of the cattle of zones like the Jewel and other agricultural areas bordering to the city. These agricultural areas supply nutritional products to the own inhabitants of the city of Arequipa, existing the potential risk of a generalized epidemic. Generally the urban industry and areas are not separated and therefore the industrial waste waters and the served waters urban are mixed in the rivers, which make difficult the determination of the contamination contribution that corresponds to him to the industry. Without a doubt, the industries in the city contribute with a portion of load in relation to total the polluting load. Nevertheless, still the real magnitude of the contribution of each industry is not known, due to the lack of technical information and to the little cooperative attitude of these. The investigation this focused to develop a proposal to optimize the productive processes using biochemical alternative technologies for the treatment of its waste waters. The investigation can be justified from the following points of view:

- Technological justification: The suitable technological parameters for the previous treatments of the industrial effluents will be determined before these are spilled to the water-drainage and later to the Chili River.

- Social justification: The Chili River would stop being a dead river since to its waters, took a load of minimum chromium residues, the one that will be monitored by the permissible limit according to the international norms. The degree of contamination of chromium of the effluents of the industry of the tanning in Arequipa can be fallen, with the recovery of some additives and by means of a treatment with aquatic plants. The involved variables are: Dependent variable: Concentration of Chromium III and total treated water Chromium (mg/l).

Independent variables: Concentration of Chromium III and feeding total water Chromium (mg/l), time of residence in moist soil ( $\mathrm{min}$ ), continuation to the natural development of the plants (vitality, Color of leaves, Growth of the stem and leaves, Chromium Concentration III and total Chromium in the root and stem of the plants).

Key words: chromium III, coliforms, effluents, waste water.

\section{INTRODUCCIÓN}

\section{La tecnología de los humedales}

Son sistemas de depuración naturales que se caracterizan por su simplicidad de operación, un bajo o nulo consumo energético, una baja producción de residuos, un bajo impacto ambiental y una buena integración al medio ambiente rural.

Las plantas acuáticas, que constituyen la base de la tecnología de los humedales, tienen la pro- piedad de dirigir grandes cantidades de oxígeno hacia sus raíces. El aire que no es aprovechado por la especie y que esta expele es absorbido por microorganismos, como bacterias y hongos, que se asocian a la raíz y se encargan de metabolizar los contaminantes que ingresan al sistema. El pantano reemplaza a diversas tecnologías de tratamiento convencionales, que realizan la misma tarea pero con un costo energético mucho más alto.

Los sistemas de tratamiento de aguas por tierras húmedas comprenden procesos distintos. 
- Los residuos pasan primero por una fosa decantadora de tres compartimientos, para luego ser depositados en forma de líquido en el humedal artificial.

- Allí las aguas escurren bajo un lecho de piedras en el que se plantan las especies acuáticas que impiden la aparición de cualquier rastro de mal olor y la proliferación de zancudos, dejándolas aptas para ser descargadas en cursos de agua o usadas para el riego.

\section{Procesos de absorción del cromo}

Los residuos provocados por la erosión de depósitos naturales y los efluentes industriales que contienen cromo (principalmente de las curtiembres) se incorporan a los cuerpos de aguas superficiales. La forma química dependerá de la presencia de materia orgánica en el agua, pues si está presente en grandes cantidades, el cromo VI se reducirá a cromo III, que podrá ser absorbido por las partículas o formar complejos insolubles.

$$
\begin{aligned}
& 2 \mathrm{Cr}_{2} \mathrm{O}_{7}^{-2}+16 \mathrm{H}^{+} \Rightarrow 4 \mathrm{Cr}^{+3}+8 \mathrm{H}_{2} \mathrm{O}+3 \mathrm{O}_{2} \\
& \Delta \mathrm{G}^{\mathrm{o}}{ }_{298 \mathrm{~K}}=-115.8 \mathrm{KJ}
\end{aligned}
$$

Estos complejos pueden permanecer en suspensión y ser incorporados a los sedimentos. La proporción de cromo III es directamente proporcional a la profundidad de los sedimentos. En teoría, el cromo VI puede resistir en este estado en aguas con bajo contenido de materia orgáni$\mathrm{ca}$, mientras que con el $\mathrm{pH}$ natural de las aguas, el cromo III formará compuestos insolubles, a menos que se formen complejos. Se desconoce la proporción relativa de cromo III y cromo VI en las aguas.

El mecanismo de cómo actúan las plantas acuáticas se produce a través de formaciones de complejos entre el metal pesado (cromo) y los aminoácidos presentes dentro de la célula, previa absorción de estos metales a través de las raíces (Metcalf y Hedí, 1995).

Otro posible mecanismo sugiere que los microorganismos presentes en las raíces producen sólidos que floculan y luego sedimentan por gravedad (Novotny and Olem, 1994).

\section{Objetivos}

Los objetivos de la presente investigación son los siguientes:

- Obtener concentraciones de cromo III y cromo total en aguas tratadas dentro del nivel permitido en aguas industriales según normas.

- Optimizar el tratamiento de aguas residuales con cromo, reduciendo el área de los humedales.

\section{MATERIAL Y MÉTODOS}

\section{Humedal de flujo subsuperficial}

El área y volumen del humedal dependerá del volumen del efluente tratado, como también de la cantidad de contaminantes presentes. Se realizará un diseño a nivel de laboratorio.

En el lecho del humedal se encuentra una capa de arcilla dispuesta en forma escalonada, encima de la cual se encuentra una capa de grava (medio poroso). El diámetro de la grava varía de acuerdo a la zona. En la zona de entrada y salida será de $2^{\prime \prime}$, y en la zona de tratamiento será de $1 "$.

Las plantas que se van a utilizar son: Phragmites para la zona de tratamiento y salida, y Scirpus para la zona de ingreso, que son plantas acuáticas con las que contamos en nuestra ciudad. La biomasa, el material vegetal y los activadores de bacterias que se utilizarán serán los propios de nuestra región (aserrín de madera, estiércol de 


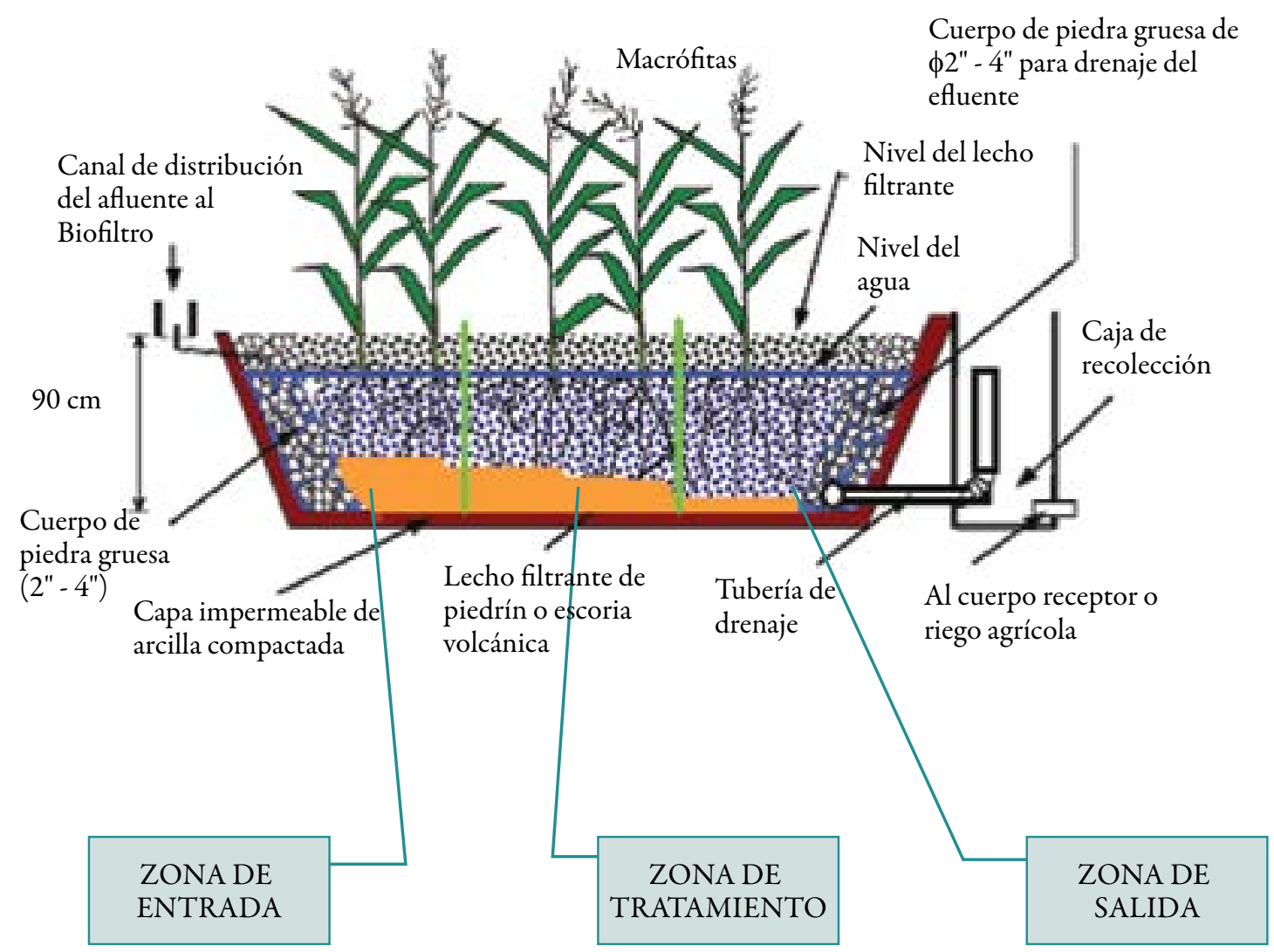

vacunos y de otros animales), y en el desarrollo de la investigación determinaremos la proporción adecuada de cada uno de ellos.

\section{Análisis fisicoquímicos}

Durante la investigación se realizarán análisis de cromo, de los sólidos totales (SST), de la demanda bioquímica de oxígeno (DBO) y de la demanda química de oxígeno (DQO) y $\mathrm{pH}$ de las muestras. Los análisis se realizarán de acuerdo al protocolo de Standard Methods.

\section{Metodología experimental}

Una vez que se tenga el humedal con la grava, se realizarán las pruebas hidráulicas con agua limpia, con la finalidad de probar que el flujo sea de tipo subsuperficial y que no tenga fugas. La siguiente etapa será la fase de siembra, en la que plantaremos dos tipos de macrófitas, las cuales serán obtenidas de las riberas del río Chili. Se alimentará el humedal con agua lim- pia hasta que las raíces de las macrófitas se aferren al medio. La densidad de las macrófitas será de 10 macrófitas $/ \mathrm{m}^{2}$. Asimismo, en esta etapa se agregará el sustrato, que ayudará a un mejor desarrollo de las macrófitas y activará las bacterias.

Se iniciará la alimentación del humedal con el efluente de las curtiembres, y después de una semana se iniciará la toma de muestras de monitoreo.

Se realizarán 6 pruebas de monitoreo cada 7 días, en las cuales se tomarán muestras de los efluentes de ingreso y de los de salida.

\section{RESULTADO}

Las plantas que se van a utilizar son Phragmites para la zona de ingreso y salida, y Scirpus para la zona de tratamiento, las mismas que han sido obtenidas de las riberas del río Chili. 


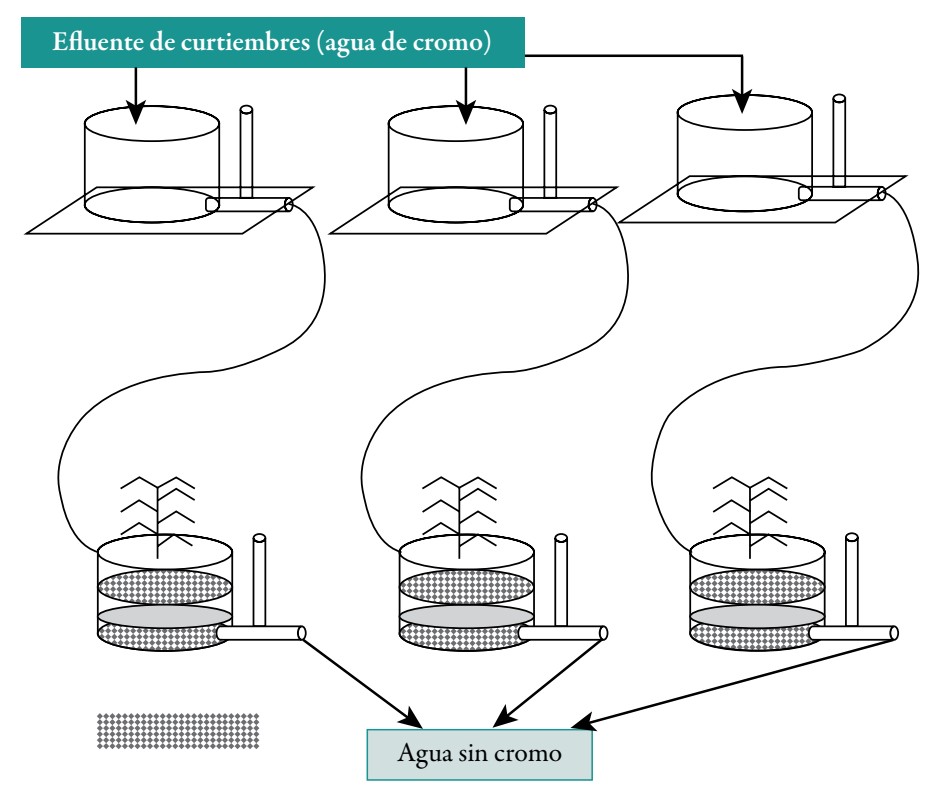

DIAGRAMA HUMEDAL VERTICAL - A NIVEL LABORATORIO ING. ROSA MARIA SOTOMAYOR

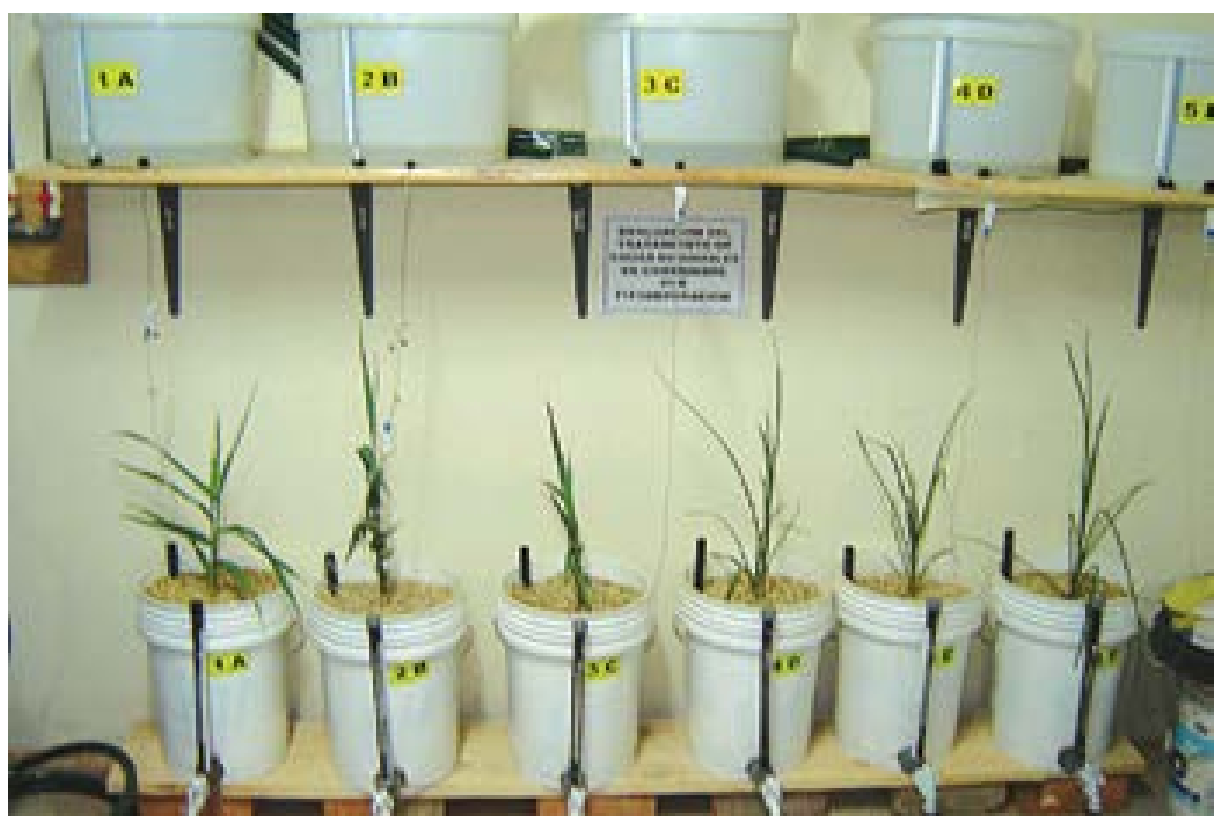

Según los análisis cualitativos, la concentración de cromo III y cromo total es alto, pero después del tratamiento podemos determinar que no hay presencia de cromo III y de cromo total.

Se realizará un diseño de experimentos combinando las variables anteriormente descritas, valiéndonos de un método de análisis cuantitativo por colorimetría y utilizando un kit de medición de la concentración de cromo III y de cromo total, previamente validado con el método espectrofotométrico.

\section{REFERENCIAS BIBLIOGRÁFICAS}

1. Álvarez, S.G., Maldonado, M., Gerth, A. et al. "Caracterización del agua residual de curtiduría y estudio del lirio acuático en la recuperación de cromo". Inf. tecnol., 2004, vol.15, No 3, p.75-80. ISSN 0718-0764.

2. Oviedo, Juan Manuel. Propuesta de asignaciones de agua en bloque (volúmenes anuales y mensuales) para la formalización de los de- 
rechos de los usos de agua en los valles Chili Regulado y Vitor, Chili no regulado e irrigación La Joya del programa de formalización de derechos de usos de agua. PROFODUA, 2004.

3. Pautrat, Lucila. Estado del medio ambiente en la región Arequipa. Septiembre de 2005.

4. Montalvo García, B. Jannibal. Tratamiento biológico de efluentes industriales usando el cultivo de carrizos. 2003.

5. Ministerio de Industria, Turismo e Integración. Propuesta de LMP (Limites Máximos Permitidos). Dirección de Asuntos Ambientales, Subsector Curtiembres, julio de 2001.

6. Comisión Nacional del Medio Ambiente (Chile). Guia para el control y la contaminación industrial: curtiembre. Santiago, 1999.
7. Iboni Fernández Paz. Contaminación físicoquímica del río Chili de Arequipa, años 1972 a 1982 y del 2003 al 2005. Arequipa, Perú 2005.

8. Caselles Osorio y J. García. Eliminación de materia orgánica disuelta y particulada en humedales construidos experimentales. Cataluña, España.

9. T. García. Diseño, construcción y evaluación preliminar de un humedal de flujo superficial. Colombia.

10. Kirk Othmer. Enciclopedia de tecnologia quimica. EE. UU.

11. Jaime Lara Borreo. Depuración de aguas residuales municipales con humedales artificiales, Barcelona, España.

12. Lucila Pautrat. Estado del medio ambiente en la región Arequipa. 2005. 